\section{Partial trisomy 12q: report of a case and review}

SUMMARY A malformed male infant with pure partial trisomy $12 \mathrm{q}(\mathrm{q} 24 \cdot 1 \rightarrow \mathrm{qter})$, resulting from an unbalanced segregation of a paternal balanced translocation $\mathrm{t}(2 ; 12)(\mathrm{q} 37 ; \mathrm{q} 24 \cdot 1)$, is described. The cytogenetic and clinical abnormalities of the proband are compared with those of four previously reported cases of partial trisomy 12q, two of which also appear to have pure trisomy of segment $12 \mathrm{q} 24 \cdot 1 \rightarrow 12$ qter.

There are, apparently, only four previously reported cases with any significant partial trisomy $12 \mathrm{q}^{1-4}$ two of which appear to have no other chromosome imbalance. $^{2} 4$ Here we describe the clinical and

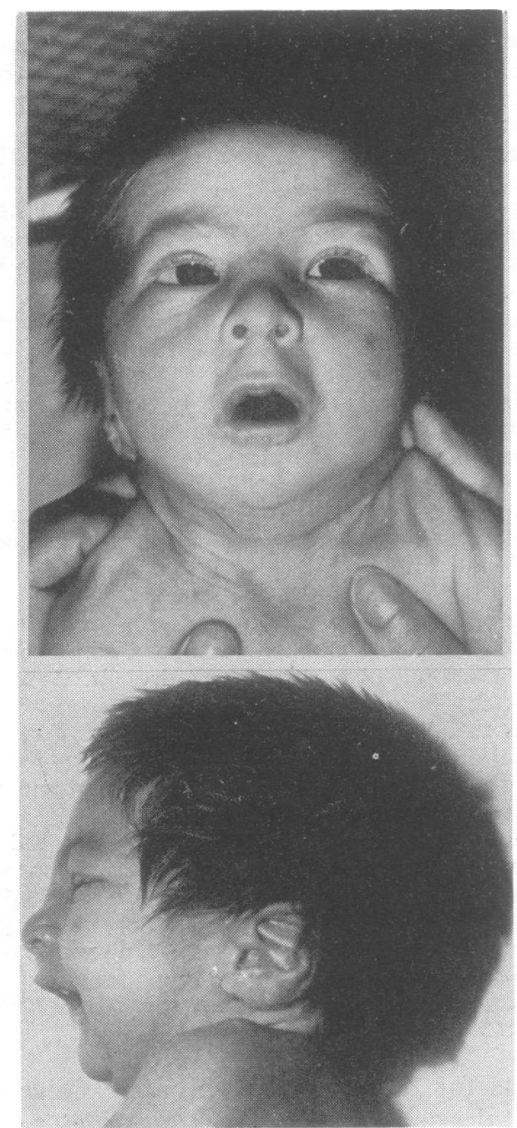

FIG 1 Front and side view of proband at 5 weeks.

Received for publication 21 January 1981 cytogenetic abnormalities in a new case of pure $\mathbb{D}$ partial trisomy $12 \mathrm{q}$, compare the findings with those $\stackrel{\oplus}{\rightarrow}$

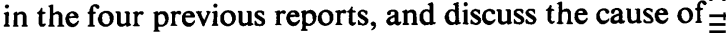
the low incidence of this anomaly.

\section{Case report}

The proband was born after an uncomplicated $\stackrel{\mathbb{Q}}{\Omega}$ pregnancy and delivery at 36 weeks' gestation. His parents, who already had a normal daughter, were ${ }_{-}$ unrelated and healthy. The mother was aged 22 years. and the father 25 years. There was no family history $\overrightarrow{\vec{\omega}}$ of spontaneous abortions or stillbirths. At birth the proband weighed $2650 \mathrm{~g}$ and his Apgar score was 9. During the first week he received surgical correction. of anal stenosis but otherwise his neonatal period $\overrightarrow{0}$ was normal.

On presentation at the Clinica Pediatrica, $\stackrel{\oplus}{\triangle}$
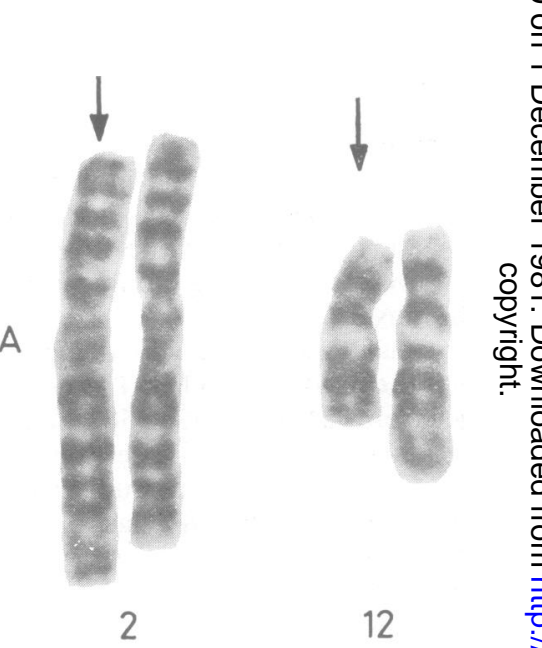

$$
\infty
$$

$$
\text { s. }
$$

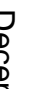

(1)


University of Catania at 5 weeks, his weight was $2850 \mathrm{~g}$, length $46.5 \mathrm{~cm}$, and head circumference $34.5 \mathrm{~cm}$. He had an odd facies (fig 1, table), a short neck with redundant skin folds, clenched hands with overlapping fingers and clinodactyly of fingers 3 and 5 , bilateral hammer toes, a sacral dimple, a small penis, and undescended testes. A cardiac systolic murmur was audible along the left sternal border and $x$-ray investigation revealed enlargement of the left third cardiac arch. Dermatoglyphic studies showed bilateral transverse single palmar creases and hypoplasia of the digital dermal ridges with a finger tip pattern of $5 \mathrm{~A}, 4 \mathrm{Lu}$, and $1 \mathrm{~W}$. Both eyes showed myopic refraction.

On re-examination at 4 months, the previously noted abnormalities were still evident and the child showed severe physical and psychomotor retardation.

\section{CYTOGENETIC STUDIES}

Chromosome preparations were obtained from peripheral blood using standard techniques ${ }^{5}$ and GTG banded ${ }^{6}$ with a method modified from that of Seabright. ${ }^{7}$ The karyotype of the father was shown to be $46, \mathrm{XY}, \mathrm{t}(2 ; 12)(\mathrm{q} 37 ; \mathrm{q} 24 \cdot 1)$ (sub-division of

TABLE Cytogenetic and clinical details in cases of partial trisomy $12 q$

\begin{tabular}{|c|c|c|c|c|c|}
\hline & \multicolumn{2}{|c|}{ Cases with an associated significant monosomy } & \multicolumn{3}{|c|}{ Cases with a pure partial trisomy } \\
\hline & Hirschhorn et all & Prieur et al ${ }^{3}$ & Hoholth et al 2 & Hemming and Brown 4 & Present case \\
\hline \multicolumn{6}{|l|}{ Cytogenetic findings } \\
\hline Karyotype & $\begin{array}{l}46, X X, \operatorname{der}(4), \\
t(4 ; 12)(q 26 ; q 12) \text { pat }\end{array}$ & $\begin{array}{l}46, X Y, \operatorname{der}(9) \\
\mathrm{t}(9 ; 12)(\mathrm{q} 21 ; \mathrm{q} 24 \cdot 2) \\
\text { mat }\end{array}$ & $\begin{array}{l}46, X Y, \operatorname{der}(21) \\
t(12 ; 21)(q 24 \cdot 1 ; p 11) \\
\text { mat }\end{array}$ & $\begin{array}{l}46, X X, \operatorname{der}(18), \\
t(12 ; 18)(q 24 \cdot 1 ; q 23) \\
\text { pat }\end{array}$ & $\begin{array}{l}46, X Y, \operatorname{der}(2) \\
t(2 ; 12)(q 37 ; q 24 \cdot 1) \\
\text { pat }\end{array}$ \\
\hline Segregation & $\begin{array}{l}\text { Adjacent } 1 \text { or } \\
\text { alternate }\end{array}$ & $\begin{array}{l}\text { Adjacent } 1 \text { or } \\
\text { al ternate }\end{array}$ & $\begin{array}{l}\text { Adjacent } 1 \text { or } \\
\text { alternate }\end{array}$ & $\begin{array}{l}\text { Adjacent } 1 \text { or } \\
\text { alternate }\end{array}$ & $\begin{array}{l}\text { Adjacent } 1 \text { or } \\
\text { alternate }\end{array}$ \\
\hline $\begin{array}{l}\text { Trisomy } \\
\text { Monosomy }\end{array}$ & $\begin{array}{l}12 \mathrm{q} 12 \rightarrow 12 \mathrm{qter} \\
4 \mathrm{q} 26 \rightarrow 4 \mathrm{qter}\end{array}$ & $\begin{array}{l}12 \mathrm{q} 24 \cdot 2 \rightarrow 12 \mathrm{qter} \\
9 \mathrm{p} 21 \rightarrow 9 \mathrm{pter}\end{array}$ & $\begin{array}{l}12 \mathrm{q} 24 \cdot 1 \rightarrow 12 \mathrm{qter} \\
21 \mathrm{p} 11 \rightarrow 21 \mathrm{pter}\end{array}$ & $\begin{array}{l}12 \mathrm{q} 24 \cdot 1 \rightarrow 12 \mathrm{qter} \\
-\end{array}$ & $\begin{array}{l}12 q 24 \cdot 1 \rightarrow 12 q t e r \\
-\end{array}$ \\
\hline \multicolumn{6}{|l|}{ Clinical findings } \\
\hline Gestation (wk) & & & 44 & 36 & 36 \\
\hline Birthweight (g) & & & 3500 & 2680 & 2650 \\
\hline Head & & Trigonocephaly* & $\begin{array}{l}\text { Brachycephaly, } \\
\text { flat top }\end{array}$ & $\begin{array}{l}\text { Brachycephaly, flat } \\
\text { occiput }\end{array}$ & $\begin{array}{l}\text { Dolichocephaly, } \\
\text { ossified anterior } \\
\text { fontanelle }\end{array}$ \\
\hline Eyes & & $\begin{array}{l}\text { Upward slanting } \\
\text { palbebral fissures* }\end{array}$ & $\begin{array}{l}\text { Upward slanting } \\
\text { palpebral fissures }\end{array}$ & & $\begin{array}{l}\text { Upward slanting } \\
\text { palpebral fissures }\end{array}$ \\
\hline Ears & & & $\begin{array}{l}\text { Poorly lobulated, } \\
\text { low set }\end{array}$ & Poorly lobulated & $\begin{array}{l}\text { Malformed helix and } \\
\text { antihelix, poorly } \\
\text { lobulated, low set }\end{array}$ \\
\hline Nose & & $\begin{array}{l}\text { Short nose, }{ }^{*} \text { flat } \\
\text { nasal root,* long } \\
\text { philtrum* }\end{array}$ & $\begin{array}{l}\text { Broad bridge, down } \\
\text { turned tip, long } \\
\text { philtrum* }\end{array}$ & $\begin{array}{l}\text { Small nose, flat } \\
\text { bridge }\end{array}$ & $\begin{array}{l}\text { Narrow and flat bridge, } \\
\text { long philtrum }\end{array}$ \\
\hline Mouth & Harelip, cleft palate & Micrognathia* & Micrognathia* & & $\begin{array}{l}\text { Micrognathia, high } \\
\text { arched palate }\end{array}$ \\
\hline Neck & & & $\begin{array}{l}\text { Redundant skin } \\
\text { folds }\end{array}$ & $\begin{array}{l}\text { Short neck, } \\
\text { redundant skin folds }\end{array}$ & $\begin{array}{l}\text { Short neck, } \\
\text { redundant skin folds }\end{array}$ \\
\hline Hands and feet & & Bilateral hexadactyly & $\begin{array}{l}\text { Bilateral simian } \\
\text { crease, hammer toes }\end{array}$ & $\begin{array}{l}\text { Right hand simian } \\
\text { crease, increased } \\
\text { distance between toes } \\
1 \text { and } 2 \text { of left foot }\end{array}$ & $\begin{array}{l}\text { Bilateral simian crease, } \\
\text { clinodactyly of fingers } \\
3 \text { and } 5 \text {, clenched } \\
\text { hands, hammer toes }\end{array}$ \\
\hline Genitalia & & $\begin{array}{l}\text { Cryptorchidism, } \\
\text { hypospadias }\end{array}$ & Cryptorchidism & $\begin{array}{l}\text { Atretic follicles in } \\
\text { both ovaries }\end{array}$ & $\begin{array}{l}\text { Cryptorchidism, } \\
\text { small penis }\end{array}$ \\
\hline Anus and sacral region & & & & $\begin{array}{l}\text { Anteriorly displaced } \\
\text { anus, sacral dimple }\end{array}$ & $\begin{array}{l}\text { Anal stenosis, sacral } \\
\text { dimple }\end{array}$ \\
\hline Heart & Cardiopathy & $\begin{array}{l}\text { Coarctation of aorta, } \\
\text { patent foramen ovalis, } \\
\text { ventricular hyper- } \\
\text { trophy }\end{array}$ & Cardiopathy & & Cardiopathy \\
\hline Musculature & & $\begin{array}{l}\text { Subumbilical hernia } \\
\text { with agenesis of } \\
\text { muscles }\end{array}$ & & Hypotonia & Hypotonia \\
\hline Others & & $\begin{array}{l}\text { Disc-shaped kidneys, } \\
\text { diaphragm-like } \\
\text { incisions of liver }\end{array}$ & $\begin{array}{l}\text { Excessive hair on } \\
\text { lower back, angula- } \\
\text { tion of sternum with } \\
\text { prominent xiphoid } \\
\text { process, liver } \\
\text { enlargement, psycho- } \\
\text { motor retardation }\end{array}$ & $\begin{array}{l}\text { Single umbilical } \\
\text { artery, increased } \\
\text { nipple width, short } \\
\text { proximal limbs, } \\
\text { dislocated hips, large } \\
\text { intestine malrotation, } \\
\text { pelvic kidney, shallow } \\
\text { epiglottic valleculae, } \\
\text { brain malformation }\end{array}$ & $\begin{array}{l}\text { Thick hair with low- } \\
\text { set hairline, sparse } \\
\text { eyebrows, myopia, } \\
\text { weak cry, psycho- } \\
\text { motor retardation }\end{array}$ \\
\hline Survival & & 6 months & Alive at 2 years & $\begin{array}{l}6 \text { days (died of } \\
\text { pneumonia) }\end{array}$ & Alive at 10 months \\
\hline
\end{tabular}

*Observed in photographs only. 
$12 \mathrm{q} 24$ as in Sanchez $\left.e a^{8}\right)$ and that of the proband $46, X Y, \operatorname{der}(2), t(2 ; 12)(q 37 ; q 24 \cdot 1)$ pat (fig 2). The proband was thus trisomic for segment $12 \mathrm{q} 24 \cdot 1 \rightarrow$ 12 qter with no detectable monosomy of 2q.

The karyotype of the mother was normal but the family did not consent to cytogenetic investigation of other relevant family members, who were, however, phenotypically normal.

\section{Discussion}

Full trisomy 12 has not been reported in liveborn subjects or in cytogenetic surveys of perinatal mortalities $^{910}$ and has only very occasionally been detected in studies of spontaneous abortuses, in embryos showing an early arrest of development. ${ }^{11} 12$ Similarily, trisomy 12 mosaicism has very rarely been found. ${ }^{13}$

Cases with any significant trisomy of long arm material of chromosome 12 are also extremely rare with only four previous reports, all involving liveborn infants. ${ }^{1-4}$ In contrast, there have been many liveborn cases with trisomy of short arm material of chromosome 12, a few including the juxtacentromeric region of $12 \mathrm{q}$, for which a clinical syndrome has been delineated. ${ }^{14}$ Conversely, in balanced translocations of chromosome 12 there is far greater involvement of the long arm than the short arm..$^{15}$ This discrepancy may be an indication of the lethality of additional long arm material, which would account for the almost complete non-viability of the full trisomic condition. However, since the abnormalities in three of the cases of partial trisomy $12 q$ (present case $^{2}{ }^{3}$ ) were compatible with an extended postnatal survival, the relatively low frequency of partial trisomy $12 q$ in the liveborn population may be the result of factors other than lethality, such as a high level of alternate segregation with a low level of interstitial chiasmata. ${ }^{16}$

The case described here and the previous reports of partial trisomy $12 \mathrm{q}$ are similar in resulting from an alternate or adjacent 1 segregation (with and without an uneven number of interstitial chiasmata respectively ${ }^{16}$ ) of a parental balanced translocation (table). The exchange point on chromosome 12 in the cases described by Hobolth et al, ${ }^{2}$ Hemming and Brown, ${ }^{4}$ and the present report appears to be at $\mathrm{q} 24 \cdot 1$, resulting in trisomy of an almost identical segment of 12q. Furthermore, no monosomy of the derived chromosome could be detected in the present case and that of Hemming and Brown, ${ }^{4}$ because in both instances either the parental translocation was non-reciprocal or the exchange point was telomeric in the recipient chromosome. In addition, the report of Hobolth et $a^{2}$ can also be considered to be a pure trisomy of segment $12 \mathrm{q} 24 \cdot 1 \rightarrow 12 \mathrm{qter}$ since the absence of $21 \mathrm{p}$, resulting from the reciprocity of the parental translocation, is unlikely to have contributed $\mathbb{Q}$ to the abnormal phenotype. ${ }^{17}$ However, in the cases $\overparen{D}$ of Hirschhorn et $a l^{1}$ and Prieur et $a l^{3}$ the parental translocations were both reciprocal and almost symmetrical, resulting in trisomy of nearly the wholeo of $12 \mathrm{q}$ with monosomy of the distal half of $4 \mathrm{q}$, and흠 trisomy of segment $12 \mathrm{q} 24 \cdot 2 \rightarrow 12 \mathrm{qter}$ with monosomy of the distal half of $9 p$, respectively.

In the latter two cases it seems improbable that a definite distinction can be made between the pheno- ${ }^{\infty}$ typic expression of the partial monosomy and the $\vec{\odot}$ partial trisomy 12q. It is possible that in the case of $\overrightarrow{ }$ Hirschhorn et al, ${ }^{1}$ for which few clinical details are ${ }^{\omega}$ available, both the partial monosomy $4 \mathrm{q}$ and the partial trisomy $12 \mathrm{q}$ contributed to the abnormalities reported. However, Prieur $e t a l^{3}$ considered that the $\vec{\infty}$ clinical features in the case they described were, in the $\%$ main, consistent with the syndrome associated with partial monosomy $9 \mathrm{p}$.

It appears likely, therefore, that a phenotypic $\frac{\text { ? }}{2}$ comparison that only includes the cases with a pure partial trisomy $12 \mathrm{q}$ (present case ${ }^{24}$ ) will be more informative. The clinical features which appear to be $\mathbb{\Phi}$ common to the present case and to either or to: $h$ of 3 the other two are upward slanting palpebral fissures, ${ }^{2} \stackrel{\text { Q }}{\text { - }}$ poorly lobulated ears ${ }^{2}{ }^{4}$ which are low set, ${ }^{2}$ flat nasal $\vec{\bullet}$ bridge, ${ }^{4}$ long philtrum, ${ }^{2}$ micrognathia, ${ }^{2}$ short nec ${ }^{4}{ }^{4}$ with redundant skin folds, ${ }^{2} 4$ simian creases, hammer toes, ${ }^{2}$ cryptorchidism, ${ }^{2}$ sacral dimple hypotonia, ${ }^{4}$ cardiopathy, ${ }^{2}$ and psychomot retardation ${ }^{2}$ (table).

Although there are as yet too few cases to delineate a phenotype for partial trisomy $12 \mathrm{q}$, it is probable $\triangle$ that the consistent features in the three cases with $\overrightarrow{\vec{D}}$ pure trisomy of apparently the same segment 3 (q24.1 $\rightarrow$ qter) of chromosome 12 will form the basis of a clinical syndrome which will be defined furthero with the accumulation of more data.

The authors wish to thank Mr P J Gregory, Dr D P Duckett, and Dr R A F Macleod for their critical evaluation of the manuscript, and Professor Fo Mollica for helpful advice.

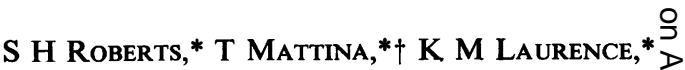
G SORGE, $\uparrow$ AND L PAVONE $\dagger$ 을

*Cytogenetics Unit, Child Health Laboratories, Department of Child Health, University Hospital of Wales, Heath Park, Cardiff, Wales, and N †Clinica Pediatrica, Viale A Doria, Università di Catania, Italy

\section{References}

1 Hirschhorn K, Lucas M, Wallace I. Precise identification $\stackrel{\$}{+}$ of various chromosomal abnormalities. Ann Hum Genet $\mathrm{D}$ 1973;36:375-9. 
2 Hobolth N, Jacobsen P, Mikkelsen M. Partial trisomy 12 in a mentally retarded boy and translocation $(12 ; 21)$ in his mother. J Med Genet 1974;11:299-303.

3 Prieur M, Couturier J, Herrault A, Lepintre J, Lejeune J. Cited in Réthoré $\mathbf{M}$. Syndromes involving chromosomes 4, 9 and 12. In: Yunis JJ, ed. New chromosomal synilromes. New York: Academic Press, 1977:119-83.

4 Hemming L, Brown R. Partial trisomy $12 \mathrm{q}$ associated with a familial translocation. Clin Genet 1979;16:25-8.

5 Moorhead PS, Nowell PC, Mellman WJ, Battips DM, Hungerford DA. Chromosome preparations of leukocytes cultured from human peripheral blood. Exp Cell Res 1960;20:613-6.

6 ISCN (1978). An international system for human cytogenetic nomenclature. Birth Defects 1978;14: No 8.

7 Seabright M. A rapid banding technique for human chromosomes. Lancet 1971 ;ii:971-2.

8 Sanchez O, Yunis JJ, Escobar JI. Partial trisomy 11 in a child resulting from a complex maternal rearrangement of chromosomes 11, 12, and 13. Humangenetik 1974;22: 59-65.

9 Machin GA, Crolla JA. Chromosome constitution of 500 infants dying during the perinatal period. Humangenetik 1974;23:183-98.

10 Kuleshov NP. Chromosome anomalies of infants dying during the perinatal period and premature newborn. Hum Genet 1976;31:151-60.

11 Boué J, Daketsé MJ, Deluchat C, Ravisé N, Yvert F, Boué A. Identification par les bandes $\mathrm{Q}$ et $\mathrm{G}$ des anomalies chromosomiques dans les avortements spontanés. Ann Genet (Paris) 1976;19:233-9.

12 Kajii T, Ferrier A, Niikawa N, Takahara H, Ohama K, Sugandhi A. Anatomic and chromosomal anomalies in 639 spontaneous abortuses. Hum Genet 1980 ;55:87-98.

13 Richer CL, Bleau G, Chapdelaine A. Trisomy 12 mosaicism in an infertile man. Can J Genet Cytol 1977;19: 565-7.

14 Kondo I, Hamaguchi $\mathrm{H}$, Haneda T. Trisomy 12p syndrome: de novo occurrence of mosaic trisomy $12 \mathrm{p}$ in a mentally retarded boy. Hum Genet $1979 ; 46: 135-40$.

15 Biederman B, Bowen P. Balanced translocations involving chromosome 12: report of a case and possible evidence for position effect. Ann Genet (Paris) 1976;19:257-60.

16 Hamerton JL. General cytogenetics. In: Human cytogenetics. Vol 2. New York: Academic Press, 1971 :248-54.

17 Neilsen J, Friedrich V, Hreidarsson AB. Frequency of deletion of short arm satellites in acrocentric chromosomes. J Med Genet 1974;11:177-80.

Requests for reprints to $\mathrm{Mr} \mathrm{S} \mathrm{H} \mathrm{Roberts,} \mathrm{Cytogenetics}$ Unit, Child Health Laboratories, Department of Child Health, University Hospital of Wales, Heath Park, Cardiff CF4 4XN.

\section{Note added in proof}

Since submission of this paper five cases of pure, or almost pure, partial trisomy of $12 \mathrm{q} 24$ have been reported. ${ }^{18-20}$ The many features common to these and to the three cases of pure partial trisomy described above support the suggestion in the concluding paragraph that pure trisomy of this region of chromosome 12 results in an identifiable clinical syndrome.

\section{References}

18 de Muelenaere A, Fryns JP, van den Berghe H. Partial distal 12q trisomy. Ann Genet (Paris) 1980;23:251-3.
19 Harrod MJE, Byrne JB, Dev VG, Francke U. Duplication $12 \mathrm{q}$ mosaicism in two unrelated patients with a similar syndrome. Am J Med Genet 1980;7:123-9.

20 Zabel B, Baumann W. Partial trisomy 12q. J Med Genet $1981 ; 18: 144-6$.

\section{Unilateral radial aplasia and trisomy 22 mosaicism}

SUMMARY A child with unilateral radial aplasia, asymmetry, other malformations, and severe physical and mental retardation is reported. In blood and bone marrow cultures a low mosaicism for trisomy 22 was found. In a few cells a chromosome 22 was missing. The importance of early cytogenetic analysis on large numbers of cells is emphasised, especially in cases of asymmetry where mosaicism is suspected.

Radial dysplasia is a relatively common limb malformation which has been associated with major anomalies in various systems, mostly genitourinary, skeletal, gastrointestinal, and cardiac. It may occur within a definite syndrome, for example, thrombocytopenia and absent radius (TAR), Holt-Oram syndrome, Fanconi's anaemia, and VATERL association, and it has also been reported in chromosomal disorders like trisomy 13 and $18 .{ }^{1}$

We describe a child with total unilateral radial aplasia associated with a clustering of defects on the same side, in whom trisomy 22 mosaicism was demonstrated.

\section{Case report}

A $2900 \mathrm{~g}$ female child was born after a normal pregnancy and delivery to non-consanguineous parents of Arabic origin. The 25-year-old mother, the 36-year-old father, and the four other children were healthy. There was no history of any congenital anomaly in the family.

A clustering of malformations was evident on the left side including a small palpebral fissure with slight ptosis, hypotrophy of the cheek, a low set ear with abnormal configuration of the helix, and mild stenosis of the external auditory canal. Total left radial aplasia with absent thumb was present (fig 1). The left forearm, hand, and the four medial fingers were smaller than those on the right side and there was colateral clinodactyly of the little finger with only one transverse crease on the left.

Repeated blood counts, including platelet and Received for publication 14 January 1981 